\title{
Physicochemical and Bacteriological Characterization of Industrial Wastewater Being Discharged to Surface Water Bodies: Significant Threat to Environmental Pollution and Human Health
}

\author{
Muhammad Tariq, ${ }^{1}$ Alia Anayat, ${ }^{2}$ Muhammad Waseem (iD, 1 \\ Muhammad Hidayat Rasool $@$, ${ }^{1}$ Muhammad Asif Zahoor, ${ }^{1}$ Shafaqat Ali $(1),{ }^{3,4}$ \\ Muhammad Rizwan, ${ }^{3}$ Mohamed M. Abdel-Daim $(1),{ }^{5,6}$ and Saad Alkahtani $\oplus^{5}$ \\ ${ }^{1}$ Department of Microbiology, Faculty of Life Science, New Campus, Government College University, 38040 Faisalabad, Pakistan \\ ${ }^{2}$ Soil \& Water Testing Laboratory, Ayub Agricultural Research Institute, Jhang Road, 38000 Faisalabad, Pakistan \\ ${ }^{3}$ Department of Environmental Sciences and Engineering, Government College University, Faisalabad-38000, Pakistan \\ ${ }^{4}$ Department of Biological Sciences and Technology, China Medical University, Taichung 40402, Taiwan \\ ${ }^{5}$ Department of Zoology, College of Science, King Saud University, P.O. Box 2455, Riyadh 11451, Saudi Arabia \\ ${ }^{6}$ Pharmacology Department, Faculty of Veterinary Medicine, Suez Canal University, Ismailia 41522, Egypt
}

Correspondence should be addressed to Muhammad Waseem; muhammad.waseem@gcuf.edu.pk and Shafaqat Ali; shafaqataligill@gcuf.edu.pk

Received 15 February 2020; Revised 27 April 2020; Accepted 4 May 2020; Published 23 May 2020

Academic Editor: Franck Rabilloud

Copyright (c) 2020 Muhammad Tariq et al. This is an open access article distributed under the Creative Commons Attribution License, which permits unrestricted use, distribution, and reproduction in any medium, provided the original work is properly cited.

\begin{abstract}
In developing countries, various sociodemographic and climatic factors such as urbanization, industrialization, and improved living standard, and water and energy demands will all characterize wastewater's future. Increasing population and water shortage are the main driving forces for the reuse of untreated wastewater for irrigation and other uses in many poor countries, posing a significant threat to global food security. Although wastewater contains essential nutrients required for plant growth, it also contains toxic heavy metals and pathogens that pose a significant threat to the environment and human health. Present research work was carried out to study important physicochemical and microbiological parameters of industrial wastewater collected from various discharged points at different locations of Kala Shah Kaku (KSK) city, Pakistan. Physicochemical parameters such as pH, temperature, sodium, calcium, magnesium, bicarbonates, sodium adsorption ratio, chlorides, and heavy metals such as nickel, cadmium, and iron of all industrial wastewater samples were within the standard limits. However, certain water's quality parameters such as TSS, BOD, COD, residual sodium carbonate, heavy metals such as chromium, and total suspended solids of all samples were exceeding the maximum allowable limits listed by Pakistani Standards. Carbonates, manganese, and cobalt were not detected in any of the wastewater samples. Total viable count and total coliform counts were higher in all samples describing low levels of sanitation. Contamination of fecal coliform and Escherichia coli was observed in about 50\% of the studied wastewater samples. The overall results focus on the discharge of highly polluted wastewater in and around KSK city. Indirectly it creates significant threats to environmental pollution and human health. Continuous monitoring of physicochemical and microbial indicators of effluent's quality for its reuse for irrigation purpose is proposed to safeguard the public health and environment.
\end{abstract}

\section{Introduction}

Anthropogenic activities such as industrialization and urbanization have resulted in an adverse impact on the ecosystem in terms of deterioration and scarcity of fresh water
[1], posing a significant threat to global food security [2]. About $60 \%$ of the world's population may undergo physical shortage of water by the year 2025 [3]. Thus, higher water demands of increasing population are considered the main driving forces for the reuse of wastewater for urban and 
periurban irrigation in many countries [4] in order to satisfy their food requirements. Wastewater can originate from amalgamation of industrial, domestic, commercial, or agricultural activities and stormwater. In developing countries, like Pakistan, poor farmers often depend on wastewater for cultivating various crops [5] preferring short-term economic benefits while ignoring the associated major health and environmental jeopardies due to lack of knowledge [6].

In the recent past, many countries in North America and Europe were used to dispose off wastewater in agricultural fields to avoid contamination of fresh water bodies [7]. On the other hand, majority of countries in Asian and African regions such as China, India, Pakistan, Egypt, and Morocco are still using untreated wastewater as a source of essential nutrients [8] for producing food crops [9].

Due to increasing anthropogenic activities, the gap between supply and demand of fresh water is continuously mounting in almost all regions of the world including Pakistan. Pakistan, once a water-surplus country, is now becoming water deficient, for example, amount of water available per capita has already been reduced from 1299 cubic meters $\left(\mathrm{m}^{3}\right)$ to $1,100 \mathrm{~m}^{3}$ and it has been expected that it will be less than $700 \mathrm{~m}^{3}$ per capita by the year 2025 against the worldwide standard of $1500 \mathrm{~m}^{3}$ [10-12]. In Pakistan, the major contributor to water pollution includes food processing industries, textile, paper and pulp, tanneries, steel, petrochemicals, chemicals, sugars, and refining industries $[10,13]$. On a daily basis, about 2,000 million gallons $\left(7.5708 \times 10^{9} \mathrm{~L}\right)$ of wastewater is discharged directly into local surface water $[11,12]$ without pretreatment.

The direct discharge of untreated industrial and municipal wastewater into drains, canals, or rivers actually worsens the water pollution. In addition, higher concentration of various pollutants may increase electrical conductivity (EC), $\mathrm{pH}$, total suspended solids (TSS), total dissolved solids (TDS), chemical oxygen demand (COD), biological oxygen demand (BOD), metals such as $\mathrm{Ni}, \mathrm{Cr}, \mathrm{Pb}$, and $\mathrm{Cd}$, and fecal coliform, thus making such water unsuitable for drinking and irrigation purposes. Therefore, treatment of wastewater prior to human use (for irrigation, drinking, landscape, etc.) becomes necessary for the protection of public health and ecosystem [14]. This is because it serves humanity in both ways such as (i) through the provision of the fresh water to irrigate agricultural land and (ii) minimizing its exposure to the environment, thus reducing the environmental pollution and shielding the public health in general $[15,16]$. On the other hand, treatment of industrial effluent is a highly sophisticated technique of engineering science in order to proficiently treat the effluent $[17,18]$. Pakistan being a developing country, small amount $(<8 \%)$ of industrial effluent is treated proficiently whereas remaining is released directly in canals, rivers, and other water bodies without performing any sort of processing as required by environmental protection agencies [5].

Kala Shah Kaku (KSK) is an industrial state near Lahore, and pollution problem is more acute in severity as wastewater generated by various steel industries is discharged directly into Deg Nalla that ultimately drops into River Ravi. In addition, industrial discharge is mixed with municipal wastewater, thus spoiling the sewage and making it unsuitable for irrigation purposes. This increasing trend of pollution of surface water bodies due to direct and untreated discharge of wastewater has become a matter of great concern. In addition, no systematic studies have been carried out to investigate the prevailing levels of pollution in order to anticipate its future effects. Many reasons for this effect included lack of laboratory facilities, nonavailability of laboratory staff, lack of knowledge, poor govt. policies, and financial constraints. Therefore, the present study was carried out to study the effect of various industry effluents on surrounding water bodies in Kala Shah Kaku (KSK), Pakistan, by adopting the methods for physicochemical and microbiological analyses of the final effluents. The principal objective of the analysis was to explore the pollution status of Deg Nullah in order to find out its suitability for irrigation and other purposes.

\section{Materials and Methods}

2.1. Collection of Wastewater Samples. Wastewater samples from the main drain, i.e., Deg Nullah situated in the enterprise zone of Kala Shah Kaku (KSK) city, were collected from various discharge points of different steel industries (Figure 1). For this, dilute nitric acid was used to wash sampling bottles. These bottles were then rinsed with deionized water followed by washing (thrice) with the wastewater before they were filled. About $1000 \mathrm{ml}$ of wastewater $(500 \mathrm{ml}$ for physicochemical and $500 \mathrm{ml}$ for heavy metal analyses) was collected from the midmost of the Deg Nullah cautiously to prevent any sort of contamination. For heavy metal analyses, collected effluent's samples were filtered $(0.45 \mu \mathrm{m})$ and concentrated nitric acid (three drops in each bottle) was supplemented to preserve it. Samples were then transported to the laboratory in temperaturecontrolled boxes $\left(4^{\circ} \mathrm{C}\right)$ for physicochemical and microbiological analyses $[19,20]$.

2.2. Physicochemical and Heavy Metal Analyses. The collected wastewater samples were analyzed to determine their physicochemical characteristics such as temperature $\left({ }^{\circ} \mathrm{C}\right)$, $\mathrm{pH}$, electrical conductivity (EC), total dissolved solids (TDS), total suspended solids (TSS), chemical oxygen demand (COD), biological oxygen demand (BOD), sodium, carbonate, calcium, magnesium, bicarbonate, chloride, residual sodium carbonate (RSC), and sodium adsorption ratio (SAR) and estimation of various metal ions such as cobalt $(\mathrm{Co})$, chromium $(\mathrm{Cr})$, copper $(\mathrm{Cu})$, manganese $(\mathrm{Mn})$, lead $(\mathrm{Pb})$, iron $(\mathrm{Fe})$, zinc $(\mathrm{Zn})$, Cadmium $(\mathrm{Cd})$, and nickel $(\mathrm{Ni})$ were determined using the atomic absorption spectrophotometer $[19,20]$.

\subsection{Microbiological Analyses}

2.3.1. Total Viable Count. Pour plate method was used for the determination of total viable count in wastewater sample that actually represents the total bacterial load in a given water sample and reflects the general hygiene condition of a 

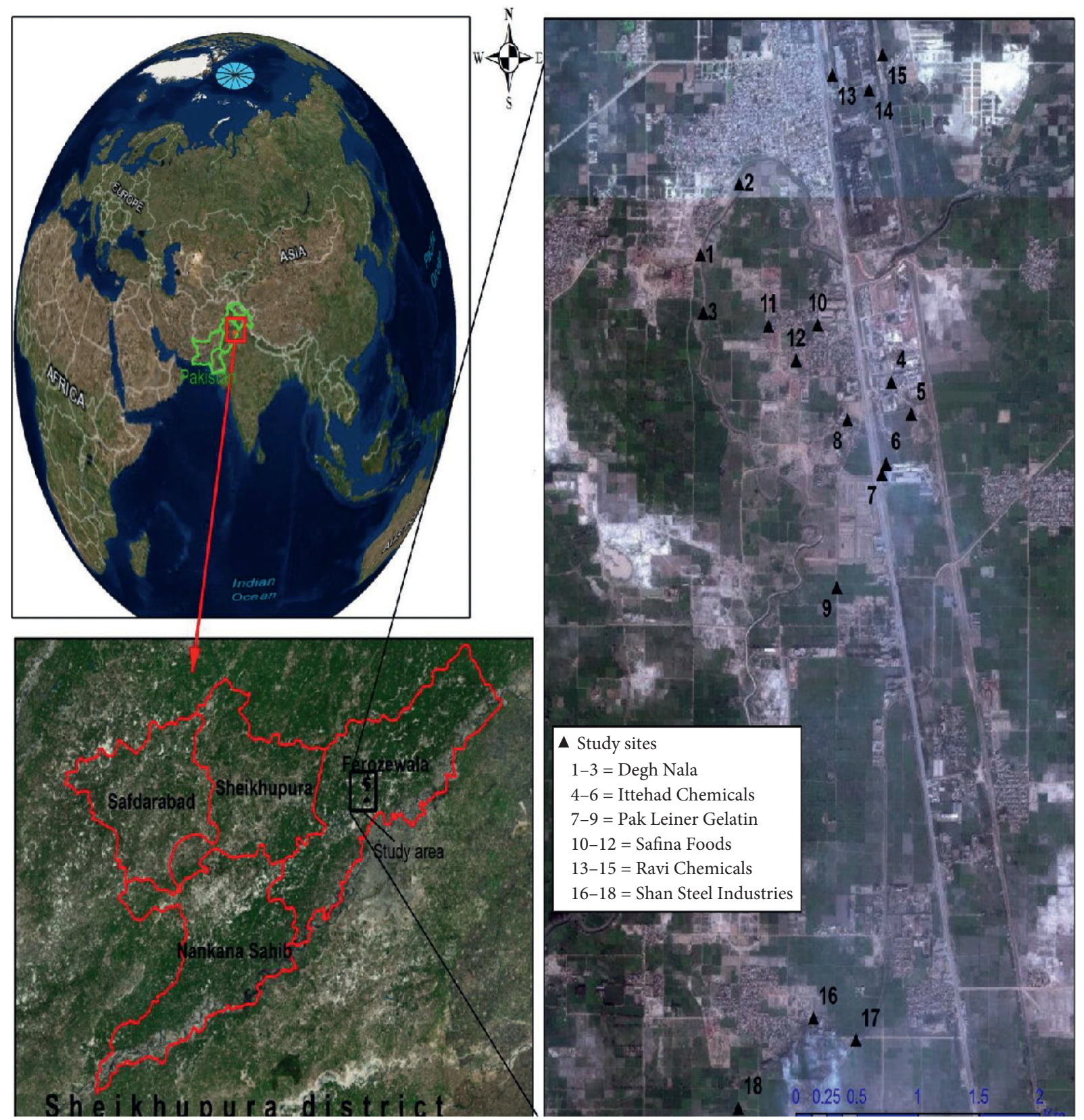

Figure 1: Wastewater sample collection points in Kala Shah Kaku industrial hub.

sample. For this, serial dilutions of wastewater prepared in sterilized water were aseptically pipetted into Petri dishes (in thrice) containing nutrient agar (Difco Laboratories, USA). Plates were swirled, solidified, inverted, and incubated at $35^{\circ} \mathrm{C}$ for 48 hours.

2.3.2. Enumeration of Fecal Coliform. The most probable number (MPN) technique was used for enumeration of fecal coliform for all wastewater samples as described by Standard Methods for the Examination of Water and Wastewater [20]. One milliliter of four dilutions $(10,100,1000$, and 10000) of each sample was added into fermentation tubes of lauryl sulfate broth (LST) in triplicate and was incubated at $35^{\circ} \mathrm{C}$ for 48 hours. Bacterial culture from all positive fermentation tubes (tubes with growth plus gas production) was transferred to fermentation tubes of EC broth and incubated at $44.5^{\circ} \mathrm{C}$ for 48 hours for fecal coliform confirmation. MPN values were calculated on the basis of gas positive tubes of both total and fecal coliform and were expressed as MPN per $100 \mathrm{ml}$. For confirmation of Escherichia coli, inoculum was transferred onto Petri dish containing Levine Eosin Methylene Blue Agar (LEMB, Oxoid) and incubated at $35^{\circ} \mathrm{C}$ for 24 hours. In Gram staining, E. coli appeared as Gram-negative short rods.

2.3.3. Statistical Analyses. Data were analyzed statistically using Minitab 2000 version 13.2 statistical software (Minitab Inc. Pennsylvania, USA). The relationship between toxic 
metal's concentration and its elemental interaction among different sectors of drain was also estimated. The $p$ value used to identify the statistical significance was $<0.05$. In order to analyze and predict the intermetal interaction and various physicochemical properties of industrial effluent, Pearson's correlation analysis was carried out.

\section{Results and Discussion}

3.1. Physicochemical Properties of the Analyzed Wastewater Samples. The mean concentration of physicochemical parameters and trace metals is given in Table 1. Majority of the wastewater samples analysed were of light yellow to yellow colour except blackish colour in site $\mathrm{B}$. The $\mathrm{pH}$ ranged from 6.02 to 8.18 for wastewater surrounding the Kala Shah Kaku city, indicating that analyzed wastewater samples fall within allowable $\mathrm{pH}$ range (i.e., 6-10) as stated by Pakistani National Environment Quality standards [21] and WHO [22]. The causes of higher $\mathrm{pH}$ may be runoff, sewage, geology, and high nutrient levels [23]. Temperature values ranged from 31 to $38^{\circ} \mathrm{C}$ found within the standard limits $\left(40^{\circ} \mathrm{C}\right)$.

Electrical conductivity (EC) is usually related to the amount of dissolved solids or minerals (ions). It means the proficiency of water to pass out an electric current. The EC value (Table 1) of all the wastewater samples ranged from 850 to $5533 \mu \mathrm{s} / \mathrm{cm}$, indicating that the majority of wastewater samples $(>83 \%)$ were not within the standard limits, i.e., $<1000 \mu \mathrm{s} / \mathrm{cm}[21,22]$.

However, in case of total dissolved solids (TDS), most of the wastewater samples analysed (about $83.3 \%$ ) had value within the standard limits $[21,22]$, and small amount of wastewater samples $(<17 \%)$ had a value above the standard limits, i.e., 3,500 mg/l for TDS [21]. The high level of TDS might be ascribed with washing of softeners, backwash of filters, and washing of reactors [24]. The total suspended solids (TSS) of all the wastewater samples exceeded the permissible limits $(150 \mathrm{mg} / \mathrm{l})$ for discharged industrial effluents $[21,22]$. Both TSS and TDS do a significant job in agriculture by affecting the plant growth, quality, and yield of crops [25].

Similarly, about $83.3 \%$ of wastewater samples analyzed were having higher levels of biochemical oxygen demand (BOD) and chemical oxygen demand (COD) that were well above the acceptable standards stated by WHO and NEQS (Table 1). It was recorded that chemical oxygen demand (COD) values were higher than BOD. This could be because BOD included only biodegradable substances whereas COD included both biodegradable and nonbiodegradable substances, although their value varies depending on the nature of substances discharged in wastewater [26]. Our results suggest that a significant amount of organic matter was present in the tested wastewater samples which can be tracked to municipal and industrial effluents including food, laundries, and steel industries [23, 27, 28]. In this study, Pak Leiner Gelatin industry (3405-3539 mg/L), Ittehad Chemicals (1664-1683 mg/L), and Deg Nullah (1491-1523 mg/L) were biggest contributors of TSS and therefore also indicated highest biochemical oxygen demand $(340-390 \mathrm{mg} / \mathrm{L}$, 296-305 mg/L, and 450-520 mg/L, respectively) and electric conductivity. Increased TDS and BOD might link to increase organic matter contents within the wastewater being discharged from various industries [26, 29-31] that will eventually disturb the aquatic life of receiving water bodies $[23,27,28]$. In addition, the release of large amount of organic matter into surface water bodies does not only increase the BOD but can also give foul odors via trapping garbage and plants which ultimately attract arthropods such as flies and mosquitoes ultimately causing diseases to nearby residents [23]. The level of certain cations such as sodium $(\mathrm{Na})$, potassium $(\mathrm{K})$, magnesium $(\mathrm{Mg})$, and calcium $(\mathrm{Ca})$ was also investigated to understand the environmental effects of discharging high-salt concentration effluents into the surface water system. It was observed that all of the wastewater samples analyzed were having concentration of $\mathrm{Na}^{+}$that exceeds the limits prescribed $(>9.0 \mathrm{me} / \mathrm{L})$ for irrigation [21, 22]. Higher amount of sodium in the wastewater may cause sodium toxicity problems in soils that could result in change in soil structure, impaired growth of plants, reduction in the yield of crops, change in the morphology of the plants, and even death [32].

Sodium adsorption ratio (SAR) indicates the amount of sodium present in wastewater relative to $\mathrm{Ca}$ and $\mathrm{Mg}$. It predicts how does sodium present in wastewater affect soil physical properties such as soil structure and water-holding capacities [33]. Values obtained for SAR (Table 1) indicated that all wastewater samples analyzed were unfit for irrigation as value of SAR was much higher than the prescribed limits $(<0.2)[21,22]$.

Sodium adsorption ratio (SAR) is the assessment which reveals the sodium absorbed by the soil and this is the indication of sodium threat. Higher level of sodium indicates when sodium makes association with mud or colloids that replaces the concentration of magnesium $(\mathrm{Mg})$ and calcium ions $(\mathrm{Ca})$ results in mutilation of soil structure and decreases the quality of soil to bear air and water [33]. As a result, level of heavy metals such as zinc ( $\mathrm{Zn})$ and iron (Fe) decreases and $\mathrm{pH}$ of soil increases that causes alterations in soil fertility. Richards [34] categorized the groundwater based on sodium adsorption ratio into three ranges: acceptable range $(<10)$, marginally acceptable range (10-18), and unacceptable range $(>18)$. In the present study, the level of sodium adsorption ration of industrial wastewater samples varied from 4.24 to 12.72. It indicates that $66.6 \%$ of samples of industrial wastewater were considered fit for irrigation and $33.3 \%$ of samples were considered marginally fit for irrigation (Table $1 ;[22])$.

Residual sodium carbonates (RSCs) determine the level of bicarbonate in wastewater. Disbanding of organic matter takes place by increasing the concentration of bicarbonate that leads to higher level of $\mathrm{pH}$ of wastewater. If the concentration of RSC increases, it causes precipitation of magnesium $(\mathrm{Mg})$ and sodium $(\mathrm{Na})$ ions that ultimately upsurge the level of sodium in the land. It was categorized as acceptable range $(<1.25)$, marginal acceptable range $(1.25-2.5)$, and unacceptable range $(>2.5)[34,35]$. In this study, the level of RSC ranged from 0.0 to $3.9 \mathrm{mec} / \mathrm{l}$, indicating that $33.3 \%$ of samples of industrial wastewater were considered fit for irrigation while $50 \%$ of samples of 


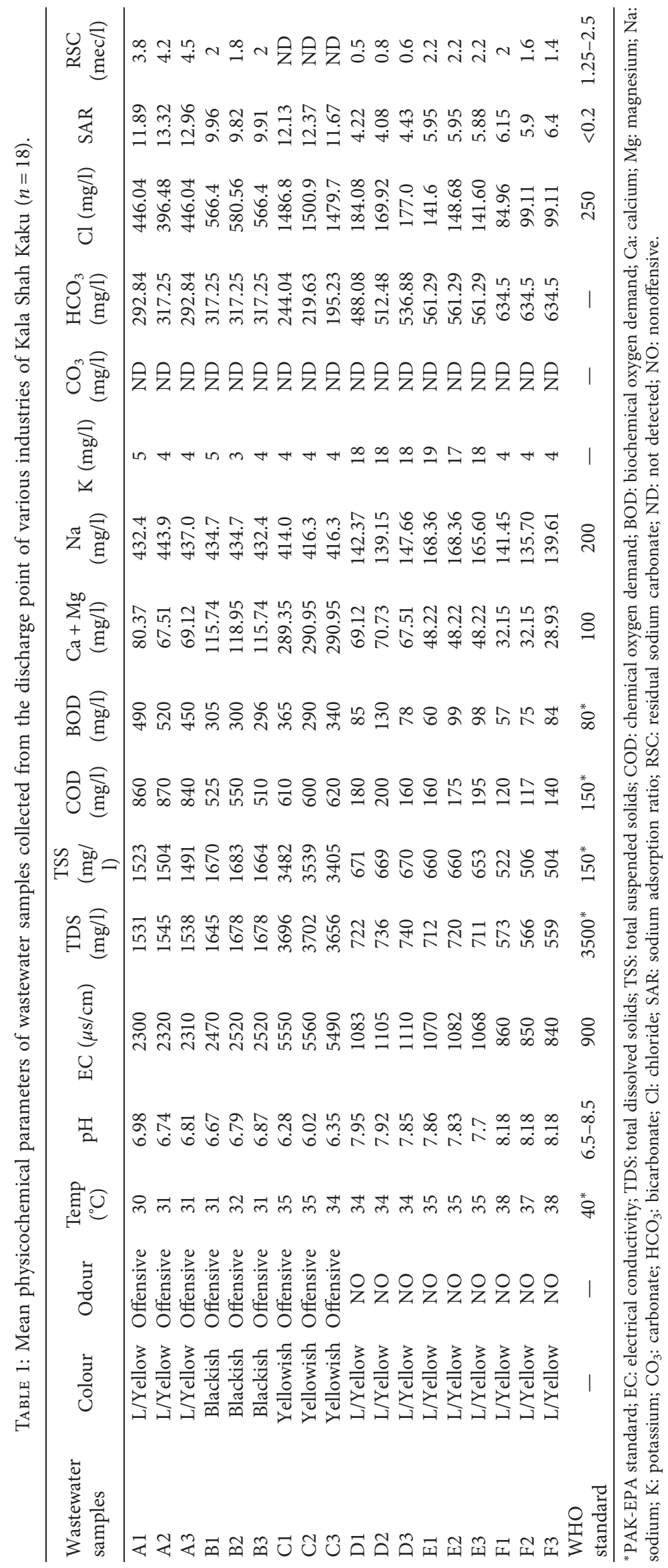


wastewater were considered marginally fit for irrigation and remaining $16.7 \%$ samples of industrial wastewater samples were considered unsuitable for irrigation. Industrial wastewater samples with high value of residual sodium carbonate can be utilized by the implementation of special irrigation and management techniques with continuous evaluation of soil salinity status through laboratory analyses [36].

All of the wastewater samples tested were lacking the carbonate $\left(\mathrm{CO}_{3}\right)$ ions, whereas level of bicarbonate $\left(\mathrm{HCO}_{3}\right)$ ranged from 3.60 to $10.40 \mathrm{meq} / \mathrm{l}$. It indicates that all tested samples of wastewater were having $\mathrm{HCO}_{3}$ contents well under permissible limits (NEQS) of $\mathrm{HCO}_{3}(1000 \mathrm{meq} / \mathrm{l})$ and considered fit for irrigation. Corrosion of metals has been done by chlorides that affect the quality and taste of food products [37]. Therefore, it does not cause any ill health effects. In the current investigation, the contents of chlorides ranged from 2.6 to $42.06 \mathrm{mg} / \mathrm{l}$ that were below the chloride allowable limits (1000 mg/l). Overall, on the basis of calcium, magnesium, sodium, carbonate, bicarbonate, chlorides, SAR, and RSC, $16.6 \%$ of the wastewater samples were discovered suitable for irrigation, $33.4 \%$ of the tested wastewater samples were discovered slightly suitable for irrigation, and $50 \%$ of the tested wastewater samples were unacceptable for irrigation at all.

3.2. Description of Toxic Metals Present in the Wastewater Samples. The concentrations of various heavy metals found in wastewater samples analyzed are depicted in Table 2. Cobalt was not detected in any of the wastewater samples (data not shown). However, other toxic metals such as $\mathrm{Cr}$, $\mathrm{Mn}, \mathrm{Ni}, \mathrm{Zn}, \mathrm{Cd}, \mathrm{Cu}, \mathrm{Pb}$, and Fe were widely distributed along different sampling sites. The most polluting metal was chromium with a maximum concentration of $12.367 \pm 0.362 \mathrm{mg} / \mathrm{L}$ found at Deg Nala, followed by Pak Leiner Gelatin $(11.75 \pm 0.089 \mathrm{mg} / \mathrm{L})$ and Shan Steel $(11.16 \pm 0.185 \mathrm{mg} / \mathrm{L})$ that was several magnitudes higher than WHO $(0.05 \mathrm{mg} / \mathrm{L})$ and PAK-EPA standards $(1 \mathrm{mg} / \mathrm{L})$ in wastewater. Second, the most contaminating metal was $\mathrm{Cd}$ with maximum concentration at Pak Leiner Gelatin industry discharge point $(0.0454 \mathrm{mg} / \mathrm{L})$ followed by Safina Food industry discharge point $(0.0435 \mathrm{mg} / \mathrm{L})$. The concentration of $\mathrm{Cd}$ was also well above the permissible limits stated by WHO $(10 \mu \mathrm{g} / \mathrm{L})$ and USEPA $(0.005 \mathrm{mg} / \mathrm{L})$ as reported in Table 2.

Other toxic metals, i.e., $\mathrm{Fe}, \mathrm{Pb}, \mathrm{Ni}, \mathrm{Cu}, \mathrm{Zn}$, and $\mathrm{Mn}$, were detectable in wastewater samples within permissible limits stated by WHO [22] and Pak-EPA. Iron contents in wastewater samples ranged from $0.308 \pm 0.002$ to $0.527 \pm 0.011 \mathrm{mg} / \mathrm{L}$ (all sites combined). Ni was also present in almost all of the wastewater samples ranging from $0.0011 \pm 0.001$ to $0.061 \pm 0.003 \mathrm{mg} / \mathrm{L}$, though it was well below the permissible limits (Pak-EPA) of Ni, i.e., $1.0 \mathrm{mg} / \mathrm{L}$. Similarly, concentration of other heavy metals ranged from $0.224 \pm 0.009$ to $0.306 \pm 0.019 \mathrm{mg} / \mathrm{L}$ for $\mathrm{Mn}, 0.029 \pm 0.013$ to $0.0737 \pm 0.02 \mathrm{mg} / \mathrm{L}$ for $\mathrm{Cu}, \quad 0.1269 \pm 0.028$ to $0.1513 \pm 40.006 \mathrm{mg} / \mathrm{L}$ for $\mathrm{Zn}$, and $0.0268 \pm 0.005$ to $0.0437 \pm 0.002 \mathrm{mg} / \mathrm{L}$ for $\mathrm{Pb}$. However, concentration of these metals in discharged wastewater was in acceptable limits set by Pak-EPA and WHO [22].

In general, wastewater samples were the most contaminated by chromium (all sampling sites combined). We know that, under aquatic conditions, chromium may undergo oxidation, reduction, sorption, and precipitation [38]. In addition, the solubility of chromium is $\mathrm{pH}$-dependent, i.e., under acidic $\mathrm{pH}$, it will tend to solubilize, and conversely, if $\mathrm{pH} \geq 7, \mathrm{Cr}$ (III) will precipitate. Moreover, Cr (VI) chromate and dichromate are extremely soluble under all $\mathrm{pH}$ conditions (Kimbrough et al. 1999). Higher solubility ultimately results in higher bioavailability of chromium to especially those plants that were being irrigated by contaminated wastewater. As chromium is nonessential to plants, it is very toxic even at low concentrations, i.e., about 0.5 to $5.0 \mathrm{mg} / \mathrm{L}$ in nutrient solution and 5 to $100 \mathrm{mg} \cdot \mathrm{g}^{-1}$ in soil [39].

Physicochemical characteristics and mean heavy metal contents of tested wastewater samples at different sampling sites $(n=18)$ were used to estimate the Pearson correlation coefficient matrix $(r)$ to determine the interaction levels of heavy metal and physicochemical properties of the analyzed wastewater samples (Table 3). Some of elemental pairs such as $\mathrm{Cd} / \mathrm{Fe}(r=0.82), \mathrm{Cd} / \mathrm{Mn}(r=0.83)$, and Fe/Mn $(r=0.52)$ were positively associated $(\alpha=0.05)$, whereas others were statistically negatively correlated (i.e., $\mathrm{Cd} / \mathrm{Ni}(r=-0.81), \mathrm{Fe} /$ $\mathrm{Ni}(r=-0.95), \mathrm{Fe} / \mathrm{Zn}(r=-0.49)$, and $\mathrm{Ni} / \mathrm{Mn}(r=-0.52))$. The elemental pairs that were positively correlated (statistically significant) suggested that these elements could have a similar source or chemical phenomenon and the inverse was true for negatively correlated element pairs found in wastewater $[26,40]$.

Certain metals also exhibited the positive and negative correlation with that of physicochemical parameters. For example, pairs Fe/pH $(r=0.67)$; Ni/COD $(r=0.82)$; Ni/BOD $(r=0.82) ; \mathrm{Zn} / \mathrm{COD}, \mathrm{BOD}(r=0.59)$; Cr/EC, TDS $(r=0.49)$; $\mathrm{Cr} / \mathrm{TSS}(r=0.5)$; Cr/COD, BOD $(r=0.70)$; and $\mathrm{Cu} / \mathrm{pH}$ $(r=0.60)$ had positive physicochemical origins. Similarly, some of these metals had significantly negative correlation such as $\mathrm{Cd} / \mathrm{COD}(r=-0.62)$; Cd/BOD $(r=-0.63)$; Fe/COD, $\mathrm{BOD}(r=-0.89)$; and Ni/pH $(r=-0.53)$ (Table 3$)$, suggesting that there was a negative correlation among these parameters and metals. These results corroborated to those obtained by Sekabira et al. [26] who reported that elemental pairs $\mathrm{Cd} / \mathrm{Mn}$ and $\mathrm{Mn} / \mathrm{Fe}$ were significantly correlated signifying similar chemical source or phenomenon. They had also observed a significant positive interaction between $\mathrm{Zn} /$ BOD, BOD/TSS, BOD/TDS, EC/TDS, TDS/TSS, and EC/ TSS that were again consistent with that obtained in this study [26].

High BOD and COD values suggested that wastewater was polluted not only with biodegradable contaminants but also with other nonbiodegradable contaminants originating from different industries. These findings may highlight the presence of significant amount of organic matter that might be present in tested wastewater samples and being discharged into main drains by various municipal and industrial sources [23, 26-31]. 
TABLE 2: Mean values and SD of heavy metal concentrations in wastewater at different sampling sites.

\begin{tabular}{|c|c|c|c|c|c|c|c|c|}
\hline \multirow{2}{*}{ Sampling sites } & \multicolumn{8}{|c|}{ Heavy metals $(\mathrm{mg} / \mathrm{L})$} \\
\hline & $\mathrm{Cd}$ & $\mathrm{Fe}$ & $\mathrm{Ni}$ & $\mathrm{Mn}$ & $\mathrm{Zn}$ & $\mathrm{Cr}$ & $\mathrm{Cu}$ & $\mathrm{Pb}$ \\
\hline ullah & $0165 \pm 0.002$ & $3080 \pm 0.002$ & $.0610 \pm 0.003$ & $0.2460 \pm 0$ & $0.1513 \pm 0$ & $12.3670 \pm 0$ & $0.0613 \pm 0$ & $0.0360 \pm 0.009$ \\
\hline $\begin{array}{l}\text { Ittehad } \\
\text { Chemicals }\end{array}$ & $0195 \pm$ & $.3630 \pm 0.018$ & $0400 \pm 0.002$ & $0.2240 \pm 0.009$ & $0.1453 \pm$ & $10.1200-$ & $0.0293 \pm 0.013$ & $0.0390 \pm 0.003$ \\
\hline $\begin{array}{l}\text { Pak Leiner } \\
\text { Gelatin }\end{array}$ & $0.0454 \pm 0.002$ & $0.4360 \pm 0.002$ & $0.0200 \pm 0.006$ & $0.3060 \pm 0.019$ & $0.1444 \pm 0.008$ & $11.7500 \pm 0.089$ & $0.0317 \pm 0.006$ & $0.0348 \pm 0.003$ \\
\hline Safina Foo & & $0.4680 \pm 0.005$ & 2 & 4 & 10 & & \pm 0.020 & $0.0437=$ \\
\hline Ravi & 4 & & 0 . & 0 & & & 0. & 0.0 \\
\hline Shan Steel & $0.0386 \pm 0.004$ & $0.5270 \pm 0.011$ & $0.0011 \pm 0.001$ & $0.2686 \pm 0.019$ & $0.1322 \pm 0.017$ & $11.1600 \pm 0.185$ & $0.0533 \pm 0.009$ & $0.0305 \pm 0.002$ \\
\hline
\end{tabular}

Cd: cadmium; Fe: iron; Ni: nickel; Mn: manganese; $\mathrm{Zn}$ : zinc; Cr: chromium; Cu: copper; Pb: lead.

TABLE 3: Pearson correlation coefficient matrix $(r)$ to determine the interaction levels of metal and physicochemical properties of the analyzed wastewater samples $(n=18)$.

\begin{tabular}{|c|c|c|c|c|c|c|c|c|c|c|c|c|c|c|}
\hline Variables & $\mathrm{Cd}$ & $\mathrm{Fe}$ & $\mathrm{Ni}$ & $\mathrm{Mn}$ & $\mathrm{Zn}$ & $\mathrm{Cr}$ & $\mathrm{Cu}$ & $\mathrm{Pb}$ & $\mathrm{pH}$ & EC & TDS & TSS & COD & BOD \\
\hline$\overline{\mathrm{Cd}}$ & 1 & & & & & & & & & & & & & \\
\hline $\mathrm{Fe}$ & 0.821 & 1 & & & & & & & & & & & & \\
\hline $\mathrm{Ni}$ & -0.810 & -0.951 & 1 & & & & & & & & & & & \\
\hline Mn & 0.832 & 0.529 & -0.527 & 1 & & & & & & & & & & \\
\hline $\mathrm{Zn}$ & -0.467 & -0.497 & 0.450 & -0.292 & 1 & & & & & & & & & \\
\hline $\mathrm{Cr}$ & -0.370 & -0.442 & 0.413 & -0.149 & 0.462 & 1 & & & & & & & & \\
\hline $\mathrm{Cu}$ & 0.174 & 0.209 & -0.031 & 0.283 & -0.409 & -0.332 & 1 & & & & & & & \\
\hline $\mathrm{Pb}$ & -0.121 & -0.282 & 0.198 & -0.085 & 0.017 & -0.343 & 0.169 & 1 & & & & & & \\
\hline $\mathrm{pH}$ & 0.301 & 0.679 & -0.535 & 0.087 & -0.480 & -0.551 & 0.608 & -0.163 & 1 & & & & & \\
\hline EC & 0.084 & -0.331 & 0.180 & 0.265 & 0.394 & 0.496 & -0.591 & 0.105 & -0.901 & 1 & & & & \\
\hline TDS & 0.084 & -0.331 & 0.180 & 0.265 & 0.394 & 0.496 & -0.591 & 0.105 & -0.901 & 1.000 & 1 & & & \\
\hline TSS & 0.044 & -0.366 & 0.211 & 0.226 & 0.409 & 0.502 & -0.607 & 0.113 & -0.918 & 0.999 & 0.999 & 1 & & \\
\hline COD & -0.620 & -0.896 & 0.825 & -0.297 & 0.597 & 0.706 & -0.348 & 0.192 & -0.845 & 0.630 & 0.630 & 0.653 & 1 & \\
\hline BOD & -0.633 & -0.895 & 0.828 & -0.315 & 0.597 & 0.702 & -0.334 & 0.197 & -0.820 & 0.602 & 0.602 & 0.625 & 0.993 & 1 \\
\hline
\end{tabular}

TABLE 4: Microbiological results of wastewater samples collected from the industrial area of KSK.

\begin{tabular}{|c|c|c|c|c|}
\hline \multirow[b]{2}{*}{ Wastewater samples } & \multirow[b]{2}{*}{ Total viable count $(\mathrm{CFU} / \mathrm{ml})$ at $37^{\circ} \mathrm{C}$ for $48 \mathrm{~h}$} & \multirow[b]{2}{*}{$\begin{array}{l}\text { Total coliform count } \\
\qquad(\mathrm{MPN} / 100 \mathrm{ml})\end{array}$} & \multicolumn{2}{|c|}{ Fecal coliform } \\
\hline & & & $\begin{array}{c}\text { Count } \\
(\mathrm{MPN} / 100 \mathrm{ml})\end{array}$ & Escherichia coli \\
\hline $\mathrm{A} 1$ & $1.31 \times 10^{4}$ & $>1.8 \times 10^{4}$ & $>1.8 \times 10^{4}$ & Detected \\
\hline A2 & $1.29 \times 10^{4}$ & $>1.8 \times 10^{4}$ & $>1.8 \times 10^{4}$ & Detected \\
\hline A3 & $1.30 \times 10^{4}$ & $>1.8 \times 10^{4}$ & $>1.8 \times 10^{4}$ & Detected \\
\hline B1 & $1.02 \times 10^{4}$ & $>1.8 \times 10^{4}$ & $>1.8 \times 10^{4}$ & Detected \\
\hline $\mathrm{B} 2$ & $1.05 \times 10^{4}$ & $>1.8 \times 10^{4}$ & $>1.8 \times 10^{4}$ & Detected \\
\hline B3 & $1.03 \times 10^{4}$ & $>1.8 \times 10^{4}$ & $>1.8 \times 10^{4}$ & Detected \\
\hline $\mathrm{C} 1$ & $1.5 \times 10^{4}$ & $>1.8 \times 10^{4}$ & $>1.8 \times 10^{4}$ & Detected \\
\hline $\mathrm{C} 2$ & $1.6 \times 10^{4}$ & $>1.8 \times 10^{4}$ & $>1.8 \times 10^{4}$ & Detected \\
\hline $\mathrm{C} 3$ & $1.5 \times 10^{4}$ & $>1.8 \times 10^{4}$ & $>1.8 \times 10^{4}$ & Detected \\
\hline D1 & $5.3 \times 10^{3}$ & $2.1 \times 10^{2}$ & Not detected & Not detected \\
\hline D2 & $5.1 \times 10^{3}$ & $2.0 \times 10^{2}$ & Not detected & Not detected \\
\hline D3 & $5.2 \times 10^{3}$ & $2.1 \times 10^{2}$ & Not detected & Not detected \\
\hline E1 & $1.28 \times 10^{4}$ & $7.0 \times 10^{2}$ & Not detected & Not detected \\
\hline E2 & $1.28 \times 10^{4}$ & $7.2 \times 10^{2}$ & Not detected & Not detected \\
\hline E3 & $1.29 \times 10^{4}$ & $7.1 \times 10^{2}$ & Not detected & Not detected \\
\hline $\mathrm{F} 1$ & $3.1 \times 10^{3}$ & $1.3 \times 10^{2}$ & Not detected & Not detected \\
\hline $\mathrm{F} 2$ & $3.0 \times 10^{3}$ & $1.4 \times 10^{2}$ & Not detected & Not detected \\
\hline F3 & $3.2 \times 10^{3}$ & $1.2 \times 10^{2}$ & Not detected & Not detected \\
\hline WHO standard & - & $\leq 1.0 \times 10^{3}$ & $\leq 1.0 \times 10^{3}$ & - \\
\hline
\end{tabular}




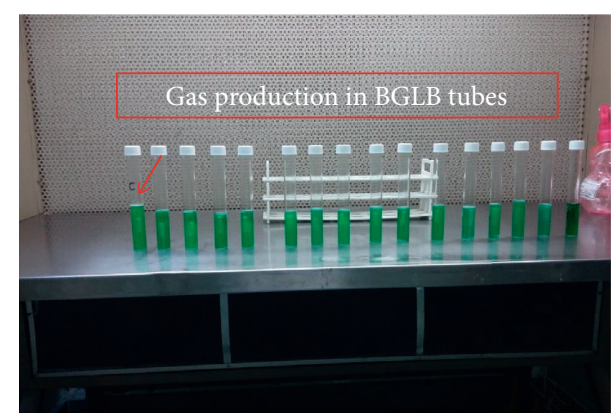

FIgURE 2: Growth of total coliform in BGLB tubes showing gas production in Durham's tubes.

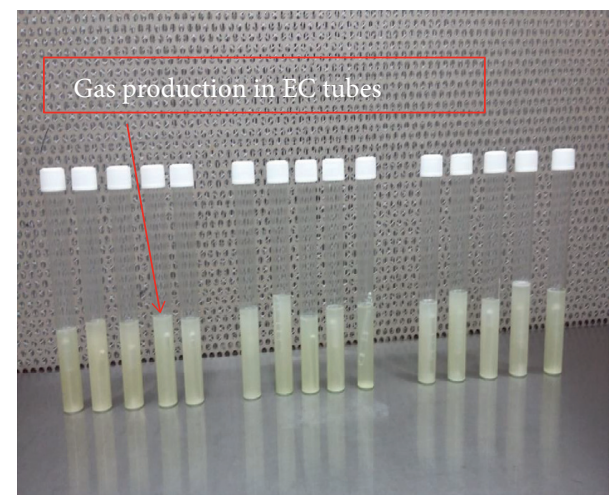

FIgURE 3: Growth of fecal coliform in EC broth tubes showing gas production in Durham's tubes.

In addition, our results also corroborated the findings of Igbinosa and Okoh (2009). They observed that higher value BOD may result in enhancement of reducing conditions in fresh water due to decomposition of organic matter as selfpurification mechanism, which indirectly could enhance the reduction of hydro-oxides of $\mathrm{Mn}$ and $\mathrm{Fe}$ [41]. Under such conditions, certain metals (Cd, Cr, etc.) could adsorb specifically to solid phase whereas lead $(\mathrm{Pb})$ may found poorly linked to crystalline oxides [42]. Under slightly to acidic conditions ( $\mathrm{pH}$ value $<6>5$ ), it could enhance the coprecipitations of different metallic ions [43,44].

\subsection{Microbiological Results of Collected Wastewater Samples.} The microbiological results of wastewater samples collected from different discharge points of industries (Figure 1) of Kala Shah Kaku are presented in Table 4 and Figures 2 and 3. As shown in Table 2 and Figure 3, higher levels of total viable count (TVC) load were observed in all the examined wastewater samples. Half of all wastewater samples (50\%) analyzed were having higher count for total and fecal coliform count (MPN/100 ml) than standard limits $\left(\leq 1.0 \times 10^{3} \mathrm{MPN} / 100 \mathrm{ml}\right)$ stated by WHO [22]. These results suggested that wastewater was not suitable for irrigating the crops. This included use of wastewater for cultivating such crops that could be consumed directly by humans (such as cucumber, lettuce, and salads) and also for irrigation of public parks and sports field. These results for FC were in

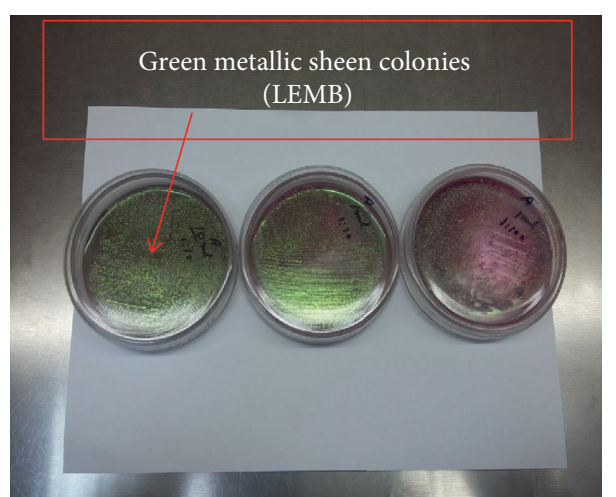

FIGURE 4: Growth of Escherichia coli on LEMB agar medium (green metallic sheen).

accordance with those obtained previously [15], who studied the wastewater samples from effluent treatment plant (Riyadh, KSA) with a mean fecal coliform value (geometric) of $7.1 \times 10^{1} \mathrm{MPN} / 100 \mathrm{ml}$, which was well below than that observed in the present study. This difference in fecal coliform count could be attributed to the efficiency of treatment plant, since in this study untreated wastewater was being discharged into surface water bodies. Furthermore, the wastewater samples that were affirmative for fecal coliform were also positive for Escherichia coli and vice versa. Escherichia coli were confirmed by streaking on LEMA agar medium as shown in Figure 4. On Gram's staining, it appeared as Gram-negative rods. Furthermore, EnteroPluri ${ }^{\circledR}$ test kit was used to confirm the Escherichia coli biochemically (Annex-1). These microbiological results focused towards the discharge of highly polluted wastewater in and around Kala Shah Kaku industrial state.

\section{Conclusion}

Majority of wastewater samples analyzed were of light yellow-to-yellow colour with $\mathrm{pH}$ ranges (6.02 to 8.18) and temperature $\left(30-38^{\circ} \mathrm{C}\right)$ within the standard limits $[21,22]$. Overall, on basis of calcium, magnesium, sodium, bicarbonate, chlorides, and residual sodium carbonate, $16.6 \%$ of wastewater samples were discovered suitable for irrigation, $33.4 \%$ of the tested wastewater samples were discovered slightly suitable for irrigation, and $50 \%$ of the tested wastewater samples were unacceptable for irrigation at all. However, on the basis of SAR, all of the tested samples of wastewater were unfit for irrigation as they could cause hardness in soil, might change the soil structure, and could affect plant growth. Various heavy metals that were detected in the analyzed wastewater samples included $\mathrm{Cr}, \mathrm{Cd}, \mathrm{Fe}, \mathrm{Ni}$, $\mathrm{Mn}, \mathrm{Cu}, \mathrm{Zn}$, and $\mathrm{Pb}$. Among them, chromium was the most polluting metal followed by cadmium (all sampling sites combined). Pearson correlation coefficient matrix suggested that there were existing of certain metal pairs that were either positively ( $\mathrm{Cd} / \mathrm{Fe}(r=0.82), \mathrm{Cd} / \mathrm{Mn}(r=0.83)$, and $\mathrm{Fe} /$ $\mathrm{Mn}(r=0.52))$ or negatively correlated $(\mathrm{Cd} / \mathrm{Ni}(r=-0.81)$, $\mathrm{Fe} / \mathrm{Ni}(r=-0.95), \mathrm{Fe} / \mathrm{Zn}(r=-0.49)$, and Ni/Mn $(r=-0.52)$. Furthermore, microbiological data of the analyzed wastewater samples suggested that it was not suitable for irrigation 
including restricted and unrestricted irrigation. Our results indicated the discharge of highly polluted municipal and industrial effluent in and around Kala Shah Kaku industrial hub.

\section{Data Availability}

All data used to support the findings of this study are included within the article.

\section{Conflicts of Interest}

The authors declare that they have no conflicts of interest.

\section{Authors' Contributions}

MT, MW, SA, and SAl conceived the idea and designed research. MT and AA conducted the experiment. MT, MAZ, and MR did the analysis. MT, MHR, SAl, MMA, and AMW analyzed the data and developed the first full draft of the manuscript. SA, SAl, and MHR critically reviewed the manuscript. All authors contributed to the subsequent development and approved the final manuscript.

\section{Acknowledgments}

The authors are grateful for financial support by Higher Education Commission of Pakistan (HEC) through Research Project \# PM-IPFP/HRD/HEC/2012/4002. This work was funded by Researchers Supporting Project number RSP 2019/26, King Saud University, Riyadh, Saudi Arabia.

\section{References}

[1] D. Molden, Water for Food Water for Life: A Comprehensive Assessment of Water Management in Agriculture, International Water Management Institute/Earthscan, London, UK, 2007.

[2] M. A. Hanjra and M. E. Qureshi, "Global water crisis and future food security in an era of climate change," Food Policy, vol. 35, no. 5, pp. 365-377, 2010.

[3] F. R. Rijsberman, "Water scarcity: fact or fiction?" Agricultural Water Management, vol. 80, no. 1-3, pp. 5-22, 2006.

[4] S. M. Scheierling, C. R. Bartone, D. D. Mara, and P. Drechsel, "Towards an agenda for improving wastewater use in agriculture," Water International, vol. 36, no. 4, pp. 420-440, 2011.

[5] J. H. J. Ensink, T. Mahmood, W. van der Hoek, L. RaschidSally, and F. P. Amerasinghe, "A nationwide assessment of wastewater use in Pakistan: an obscure activity or a vitally important one?" Water Policy, vol. 6, no. 3, pp. 197-206, 2004.

[6] D. Wichelns and P. Drechsel, "Meeting the challenge of wastewater irrigation: economics, finance, business opportunities and methodological constraints," Water International, vol. 36, no. 4, pp. 415-419, 2011.

[7] T. Asano, F. L. Burton, H. Leverenz, R. Tsuchihashi, and G. Tchobanoglous, Water Reuse: Issues, Technologies, and Applications, McGraw-Hill Professional, New York, NY, USA, 2007.

[8] B. Jimenez and T. Asano, Water Reuse: An International Survey of Current Practice, Issues and Needs, IWA, London, UK, 2008.
[9] B. N. Keraita and P. Drechsel, "Agricultural use of untreated urban wastewater in Ghana," in Wastewater Use in Irrigated Agriculture: Confronting the Livelihood and Environmental Realities, C. A Scott, N. I. Faruqui, and L. Raschid-ally, Eds., pp. 101-112, CABI Publishing, Wallingford, UK, 2004.

[10] A. Azizullah, M. N. K. Khattak, P. Richter, and D.-P. Häder, "Water pollution in Pakistan and its impact on public health-a review," Environment International, vol. 37, no. 2, pp. 479-497, 2011.

[11] I. Hashmi, S. Farooq, and S. Qaiser, "Chlorination and water quality monitoring within a public drinking water supply in Rawalpindi Cantt (Westridge and Tench) area, Pakistan," Environmental Monitoring and Assessment, vol. 158, no. 1-4, pp. 393-403, 2009.

[12] Pak-SCEA, Pakistan: Strategic Country Environmental Assessment Report, Rising to the Challenges, Pak-SCEA, Islamabad, Pakistan, 2006.

[13] Z. Aftab, L. Ali, A. M. Khan, A. C. Robinson, and I. A. Irshad, Industrial Policy and the Environment in Pakistan, United Nations Industrial Development Organization (UNIDO), Vienna, Austria, 2000.

[14] D. D. Mara, "The production of microbiologically safe effluents for wastewater reuse in the Middle East and North Africa," Environmental Challenges, vol. 123, no. 1-4, pp. 595-603, 2000.

[15] A. O. Al-Jasser, "Saudi wastewater reuse standards for agricultural irrigation: Riyadh treatment plants effluent compliance," Journal of King Saud University-Engineering Sciences, vol. 23, no. 1, pp. 1-8, 2011.

[16] J. M. Alhumoud, H. S. Behbehani, and T. H. Abdullah, "Wastewater reuse practices in Kuwait," The Environmentalist, vol. 23, no. 2, pp. 117-126, 2003.

[17] T. Asano, R. G. Smit, and G. Tchobanoglous, "Wastewater reclamation, recycling and reuse," Water Science and Technology, vol. 33, no. 10-11, pp. 1-14, 1985.

[18] National Research Council (NRC), Use of Reclaimed Water and Sludge in Food Crop Production, National Academy Press, Washington, DC, USA, 1996.

[19] APHA, Standard Methods for the Examination of Water and Waste Water, American Public Health Association, Washington, DC, USA, 20th edition, 1998.

[20] A. D. Eaton, M. A. H. Franson, American Water Works Association, Water Environment Federation, and American Public Health Association, Standard Method for the Examination of Water and Wastewater, American Public Health Association, Washington, DC, USA, 21st edition, 2005.

[21] N. E. Q. S., National Environmental Quality Standards for Municipal and Liquid Industrial Effluents, 2000, http://www. emc.com.pk/pdf/3-NEQS(New).pdf.

[22] WHO, Guidelines for Drinking-Water Quality, World Health Organization, Geneva, Switzerland, 2008.

[23] A. Hamid, M. Zeb, A. Mehmood, S. Akhtar, and S. Saif, "Assessment of wastewater quality of drains for irrigation," Journal of Environmental Protection, vol. 4, no. 9, pp. 937-945, 2013.

[24] G. Hussain, A. Alquwaizany, and A. Al-Zarah, "Guidelines for irrigation water quality and water management in the Kingdom of Saudi Arabia: an overview," Journal of Applied Sciences, vol. 10, no. 2, pp. 79-96, 2010.

[25] SFWF, TDS \& pH, Organization of Safe Drinking Water, Canada, pp. 1-6, 2002.

[26] K. Sekabira, H. O. Origa, T. A. Basamba, G. Mutumba, and E. Kakudidi, "Heavy metal assessment and water quality values in urban stream and rain water," International Journal 
of Environmental Science \& Technology, vol. 7, no. 4, pp. 759-770, 2010.

[27] R. Sahu, S. Katiyar, J. Tiwari, and G. C. Kisku, "Assessment of drain water receiving effluent from tanneries and its impact on soil and plants with particular emphasis on bioaccumulation of heavy metals," Journal of Environmental Biology, vol. 28, no. 3, pp. 685-690, 2007.

[28] WWF, "Special report: pakistan's waters at risk; water and health related issues in Pakistan and key recommendations," A special report, pp. 1-33, WWF Pakistan, Lahore, Pakistan, 2007.

[29] J. C. Akan, F. I. Abdulrahman, J. T. Ayodele, and V. O. Ogugbuaja, "Studies on the effect of municipal waste and industrial effluent on the pollutant levels of river Challawa, Kano State, Nigeria," Research Journal of Applied Sciences, vol. 2, no. 4, pp. 530-535, 2007.

[30] J. C. Akan, F. I. Abdulrahman, G. A. Dimari, and V. O. Ogugbuaja, "Physicochemical determination of pollutants in wastewater and vegetable samples along the Jakara wastewater channel in Kano Metropolis, Kano State, Nigeria," European Journal of Scientific Research, vol. 23, no. 1, pp. 122-133, 2008.

[31] O. Phiri, P. Mumba, B. H. Z. Moyo, and W. Kadewa, “Assessment of the impact of industrial effluents on water quality of receiving rivers in urban areas of Malawi," International Journal of Environmental Science \& Technology, vol. 2, no. 3, pp. 237-244, 2005.

[32] S. Toze, "Reuse of effluent water-benefits and risks," Agricultural Water Management, vol. 80, no. 1-3, pp. 147-159, 2006.

[33] J. W. Lloyd and J. A. A. Heathcote, Natural Inorganic Hydrochemistry in Relation to Ground Water, University of Oxford Press, Oxford, UK, 1985.

[34] L. A. Richards, Diagnosis and Improvement of Saline and Alkali Soils, Agriculture Handbook 60, US Department of Agriculture, Washington, DC, USA, 1954.

[35] C. Sadashivaiah, C. Ramakrishnaiah, and G. Ranganna, "Hydrochemical analysis and evaluation of groundwater quality in Tumkur Taluk Karnataka State India," International Journal of Environmental Research and Public Health, vol. 5, no. 3, pp. 158-164, 2008.

[36] S. C. Nishanthiny, M. Thushyanthy, T. Barathithasan, and S. Saravanan, "Irrigation water quality based on hydro chemical analysis in Sri Lanka," American-Eurasian Journal of Agricultural \& Environmental Sciences, vol. 7, pp. 100-102, 2010.

[37] American Public Health Association, Standard Methods for the Examination of Water and Wastewater, American Public Health Association, Washington, DC, USA, 2000.

[38] D. E. Kimbrough, Y. Cohen, A. M. Winer, L. Creelman, and C. Mabuni, "A Critical Assessment of Chromium in the Environment," Critical Reviews in Environmental Science and Technology, vol. 29, no. 1, pp. 1-46, 1999.

[39] L. R. Hossner, "Phytoaccumulation of selected heavy metals, uranium, and plutonium in plant systems," Quarterly Progress Report: Project UTA96-0043, Texas A\&M University, College Station, TX, USA, 1996.

[40] D. Kar, P. Sur, S. K. Mandai, T. Saha, and R. K. Kole, "Assessment of heavy metal pollution in surface water," International Journal of Environmental Science \& Technology, vol. 5, no. 1, pp. 119-124, 2008.

[41] P. M. Linnik and I. B. Zubenko, "Role of bottom sediments in the secondary pollution of aquatic environments by heavy- metal compounds," Lakes \& Reservoirs: Research \& Management, vol. 5, pp. 11-21, 2000.

[42] J. E. Fergusson, The Heavy Elements: Chemistry, Environmental Impact and Health Effects, Oxford Pergamon Press, Oxford, UK, 1990.

[43] K. Anazawa, Y. Kaida, T. Tomiyasu, and H. Sakamoto, "Heavy metal distribution in river waters and sediments around a "Firely village," Shikoku, Japan: application of multivariate analysis," Analytical Sciences, vol. 20, no. 1, pp. 79-84, 2004.

[44] A. Muwanga, Environmental Impacts of Copper Mining at Kilembe, Uganda: a Geochemical Investigation of Heavy Metal Pollution of Drainage Waters, Stream Sediments, and Soils in the Kilembe Valley in Relation to Mine Waste Disposal, Technical University Braunschweig, Braunschweig, Germany, 1997. 